\title{
Revista "Radiologia Brasileira" indexada na SciELO
}

A revista Radiologia Brasileira acaba de ser indexada no banco de dados SciELO. Isto significa que a partir de agora passou a ser uma publicação científica reconhecida pelo Capes, órgão do Ministério da Educação que avalia os cursos e a produção científica. As publicações nacionais indexadas por este banco são consideradas como categoria A. Isto representa que haverá maior valorização dos artigos nela publicados. Representa também que nossa publicação atingiu padrões internacionais de qualidade. Para que se tenha idéia do significado desta conquista, menos de 30 revistas médicas nacionais estão indexadas neste banco de dados.

Indiretamente, o Colégio Brasileiro de Radiologia passa a ter maior respeitabilidade do ponto de vista acadêmico e científico. Este se torna mais um serviço de qualidade que o CBR pode prestar à sua comunidade acadêmica, que, de agora em diante, tem a oportunidade de poder publicar sua produção científica em um órgão nacional, nos moldes das publicações de língua estrangeira. Tendo respeitabilidade e reconhecimento internacional, este veículo passa a ser alternativa importante para a divulgação científica da nossa comunidade, muitas vezes impossibilitada de conquistar espaço nas revistas mundialmente tradicionais, resultado da constante recusa da aceitação de trabalhos produzidos em países considerados de terceiro mundo. Estando indexada, permitirá que a comunidade radiológica internacional tenha também acesso à nossa melhor produção científica.
Para os cursos de pós-graduação existentes na Universidade de São Paulo, na Universidade Federal de São Paulo e na Universidade Federal do Rio de Janeiro, as mais produtivas do País, a indexação da Radiologia Brasileira torna a publicação um grande aliado nesta corrente de aumento da qualidade e da credibilidade da especialidade e dos especialistas em nosso meio.

Deve-se creditar o mérito desta conquista ao Prof. Dr. Giovanni Guido Cerri, que, sendo o Editor da Radiologia Brasileira durante todos estes anos, empenhou-se em manter nesta publicação o maior rigor científico associado à necessidade de garantir sua credibilidade pela preservação permanente da periodicidade preconizada e respeitada ao longo dos anos, assim como da qualidade da apresentação dos textos e de uma produção fotográfica de alto nível, comparável às melhores produções científicas mundiais no campo da Radiologia.

Como próximo passo, aspiramos todos chegar o dia em que nossa revista Radiologia Brasileira conquiste a indexação no Medline/Index Medicus, que representará o prêmio maior do reconhecimento, em nível mundial, da qualidade da Radiologia em nosso meio.

Chegaremos lá! É questão de tempo e de perseguir nossos ideais!

Luiz Karpovas Secretário do CBR 